\title{
Forest Recreation Culture of 18th Century Joseon Intellectuals - Focused on the Korean Translation of Yusangi -
}

\author{
Woo-Yeol Kim ${ }^{1}$ and Bong-Ju Park \\ ${ }^{1}$ Department of Forest Therapy, Graduate School, Chungbuk National University, Cheongju 28644, South Korea \\ ${ }^{2}$ Department of Horticultural Science, Chungbuk National University, Cheongju 28644, South Korea
}

\begin{abstract}
This study examines the forest recreation culture of Joseon intellectuals through the Yusangi (遊山記; literary works on sightseeing along the forest) translated by the Korea National Arboretum among Yusangi written in the 18th century. This study aimed to identify the forest recreation culture of the Joseon period and to explore success factors of the modern forest culture by understanding how the intellectuals saw, felt and responded to the nature by analyzing the content of Korean translation of Yusangi. The contents of the 18th century Yusangi was analyzed according to the $5 \mathrm{~W} 1 \mathrm{H}$ principle and its meanings were assumed. Specifically, this study analyzed time and reason of visit to nature, activities, their emotional feelings and changes in rational thinking of the people who recorded the Yusangi. Major findings were as follows. Most of the writers of Yusangi were intellectuals who were the ruling classes of the time. The places visited included not only the famous mountain of the whole country but also the local areas where they resided and the areas where they worked as officials. They were often looking for arithmetic to leave the excursion in order for studying mind-set and longevity during their 20 s and 30 s, or to spare time in their 50s and 60s. Findings from analysis of tourists' behavior as sensory behavior and general behavior included various visual behaviors, such as observing fish in the stream and stars in the night sky, as well as their appreciation of the scenery. In addition, auditory behaviors, such as paying attention to the sound of nature and appreciating musical instruments, and olfactory behaviors were also appeared. Typical activities were poetry writing, water activities, and nature activities. As a result of these behaviors, Yusangi exhibits various emotional feelings and expressions of rational thoughts. Despite moderation of emotional expressions, expressions of delicate emotional thoughts stimulated modern empathy. The tradition of forest recreation as a culture of Joseon intellectuals in the 18th century will be no less favorable to the modern forest recreation culture and will be a good traditional resource for enriching our forest recreation culture.
\end{abstract}

Key words: emotional feeling, 5W1H, forest recreation, korea national arboretum, visual behavior

\section{I . Introduction}

Over $60 \%$ of the national territory in Korea consists of mountains. The Korean culture is thus closely related to the geographical features of mountains, which were objects of worship and memorial service in the pre-modern society. Up until recently mountains have served as the source of tree energy for heating and cooking, as well as lumber for construction. In addition, forests and mountains also served as a natural infrastructure to prevent natural disasters, acting as a windbreak that prevents wind, drought and flood. Furthermore, forests and mountains provided relaxation and mental comfort for people, as well as a picnic area for enjoyment and a beautiful

Received on April 17, 2017. Revised on May 1, 2017.

Accepted on May 30, 2017.

*Comesponding author: bjpak@chungbuk.ac.kr landscape that offered visual pleasure (Lee, 2012). These forests and mountains have become diverse cultural backgrounds for our people. As the scientific technology and industry developed in the modern times, the source of energy changed from lumber to oil, and the type of buildings changed from wooden to metal and cement buildings, which now led forests and mountains to perform a different cultural role. The concept of 'forest recreation' was implemented in the forests of Korea as a source of physical and mental rest, and now it has developed into a form of 'forest therapy' that promotes mental and physical health of humans. In compliance with the concept of well-being introduced by the West, this developed into a forest welfare policy at the national level by linking forests and mountains to welfare (Korea Forest Therapy Forum, 2011).

Recently, concepts like forest recreation, forest therapy, and forest welfare that emerged in the process of finding another 
utility of forests are Western concepts originating from welfareoriented national policies. The Western orientation is also common in defining the academic and philosophical theories as well as principles about forest recreation or forest therapy (Kim, 2014). However, Koreans have had the cultural form of forest recreation already since the pre-modern society, also referred to as the Joseon Dynasty. This originates from the records of Yusangi (遊山記) left in the form of travel essays by intellectuals in landscape sightseeing from the late Goryeo to Joseon period (Lee, 2014). Among the aristocrats that were the ruling class of the Joseon Dynasty, those who respected Confucian study, pursued study as a career, or entered government service through this study are referred to as Sadaebu (Lee, 2011), and they can be regarded as the intellectuals of the Joseon Dynasty. Since the early Joseon period, these intellectuals enjoyed landscape sightseeing, through which they left their homes to enjoy, experience and record nature that is represented as 'landscape (山水).' There are many different terms for the records of landscape sightseeing in the Joseon period, such as Yugi (遊記), Yurok (遊錄), and Sansugi (山水記) (Lee, 2011), but since the subject of this study is the Korean translation of Yusangi published by the Korea National Arboretum, this study will use the term 'Yusangi.' As it can be seen from the title, Yusangi consists of experiences by Joseon intellectuals hanging around in the mountains, recorded mostly in the form of prose. Here, the meaning of hanging around is a direct translation of the Chinese character ' $\mathrm{Yu}$ (遊)' that is also used in other words like 'Yuhak (游學),' which does not mean to merely 'play' (Seo, 2000), but a way of study for Joseon intellectuals through sightseeing, mental and physical development, and exploration of cultural heritages (Lee, 2011). There are as many forms of Yusangi as the number of writers, and traditionally it had been in the form of recording the motive or purpose of sightseeing at the beginning and then companions, followed by what they experienced in sightseeing each day (Jung, 2013). However, in the 18th century that is the late Joseon period, the form was destroyed and the writing style and content diversified according to the writer's interests and aims (Chung, 2007).

Previous studies on Yusangi can be divided largely in terms of Chinese characters, geography and history. Research topics on the landscape travels in the late Joseon period mostly consist of those in literature or Chinese classics (Park and Sung, 1993). There are literary analyses by writer or work (Lee et al., 1997), and studies on specific regions (Kang, 2003; Park, 2005), which contributed to explaining the grounds of the ideological traditions and perceptions of landscape sightseeing (山水遊覽) and analyzing the specific works of each writer (Lee, 2014). In geography, travel notes were analyzed in terms of historical geography, and the traveler's motives, itinerary, places and images were analyzed specifically (Jung, 2003; Jung, 2009; Jung, 2013). These studies have significance in that they attempted to generalize the contents and customs of landscape sightseeing in the Joseon period, and they studied the objective environment and preparations for traveling in the Joseon period by analyzing the 18th-century travel notes (Cheong, 2006). This is a meaningful achievement in defining the traveling culture in the Joseon period as they reviewed the social environment and conditions for studying the form of travel called sightseeing. There were attempts to study sightseeing in the field of history as well. Yusangi in the Joseon period was analyzed in terms of Buddhist history to examine the situation of the Buddhist world such as the modalities of Buddhist monks and temples (Jang, 2003). Moreover, there was the first research that integrated and examined sightseeing in the Joseon period by regarding sightseeing as a cultural boost and not limiting the scope to individual writers or places (Lee, 2013). The periodic and socio-historical meaning of Yusangi was also defined by studying Yusangi that may represent each time period, after turning the late-Joseon (17-18C) Yusangi into lists and statistics to analyze the status of the writers (Lee, 2014).

The findings of these studies were in the process of determining the literary, cultural, social and historical meaning of Yusangi, and since Yusangi is a cultural outcome of the Joseon ruling class and intellectuals, such research will be continued. However, it is difficult to find any research findings in terms of forest recreation culture in the studies about Yusangi. This is because it is only recently that academic research began on forest recreation or culture, which originated from the Western concept (Park, 1986). However, the Korea National Arboretum recently published the Korean translation of Yusangi to define the historicity of forest culture, which was an important first step toward research on forest recreation and culture. It will be 
meaningful to study Yusangi to determine the culture of forest recreation in the traditional society. Therefore, by analyzing the 18th-century Yusangi in the Korean translation, this study 1) determined the Joseon forest recreation culture as a traditional origin of modern forest recreation culture, 2) found elements of modern inheritance by examining the behaviors of traditional forest recreation, and 3) examined how intellectuals in the pre-modern society saw, felt and responded to nature.

\section{Research Method}

Yusangi, which is to be analyzed in this study, is the Korean translation of Yusangi recently published by the Korea National Arboretum under the Korea Forest Service to determine the historicity of forest policies and culture. The five volumes of the Korean translation were edited by region where the visited mountains are located. They include total 103 pieces consisting of 23 in Vol. 1 Gyeongsangbuk-do, and 20 each in Vol. 2 Gyeonggi-do, Vol. 3 Gyeongsangnam-do, Vol. 4 Gangwon-do, and Vol. 5 Chungcheong-do/Jeolla-do. The years written are evenly distributed from early to late Joseon period, which is the late 19th century. Among them, this study selected and analyzed the ones written in the 18th century (1700s) (Table 1). This is because 18th-century Joseon consists of the years of Sukjong, Gyeongjong, Yeongjo and Jeongjo (Park, 1996), and the Joseon society in this period shows various changes like the inflow of foreign culture in addition to economic development. A new school and culture called Silhak (Realist School of Confucianism) also appeared, producing a whole different form of culture. Moreover, some of the ruling class accepted

Table 1. List of Yusangi analyzed.

\begin{tabular}{|c|c|c|c|c|c|}
\hline No. & Title & Author & Writing time & Mountain & Region \\
\hline 1 & Yousongnisangi & Lee Hyeonik & 1706 & Songnisan & Chungbuk \\
\hline 2 & Yousamgaksangi & Lee Ik & 1707 & Bukansan & Gyeonggi \\
\hline 3 & Taebaeksangi & Kang Jaehang & 1710 & Taebaeksan & Kangwon \\
\hline 4 & Youbukangi & Lee Ik & 1712 & Bukansan & Gyeonggi \\
\hline 5 & Youcheonmasangi & Lee Ik & 1714 & Cheonmasan & Gyeonggi \\
\hline 6 & Youkwanaksangi & Lee Ik & Unknown $^{z}$ & Kwanaksan & Gyeonggi \\
\hline 7 & Sobaekyourok & Kwon Jeongchim & 1740 & Sobaeksan & Kyengbuk \\
\hline 8 & Gosungyougi & Lee Jonghwi & 1753 & Hwawangsan & Kyeongnam \\
\hline 9 & Yougayasanrok & Choi Hyeongwon & 1757 & Gayasan & Kyeongnam \\
\hline 10 & Deungyeonjukbonggi & Chae Jaekong & 1784 & Yeonjukbong & Gyeonggi \\
\hline 11 & Youkwanaksangi & Chae Jaekong & 1786 & Kwanaksan & Gyeonggi \\
\hline 12 & Youseorakrok & Kim Monghwa. & 1787 & Seoraksan & Kangwon \\
\hline 13 & Yousongniaangi & Lee Donghang & 1787 & Songnisan & Chungbuk \\
\hline 14 & Yousuraksogi & Oh Hisang & 1790 & Suraksan & Gyeonggi \\
\hline 15 & Samdongsansugi & Lee Dongnang & Unknown $^{z}$ & Hamyang-gun & Kyeongnam \\
\hline 16 & Deungodosangi & Shin Hoin & Unknown $^{\mathrm{z}}$ & Odosan & Kyeongnam \\
\hline 17 & Yougeumsangi & Jung Hwi & $1803^{y}$ & Geumsan & Kyeongnam \\
\hline 18 & Woodusangi & Lee Insang & Unknown $^{\mathrm{z}}$ & Woodusan & Kyeongnam \\
\hline 19 & Gaeryongsangi & Kim Jaehang & Unknown $^{\mathrm{z}}$ & Gaeryongsan & Chungnam \\
\hline 20 & Youwolsangi & Shin Myeonghyeon & Unknown ${ }^{\mathrm{z}}$ & Wolsan & Chungnam \\
\hline 21 & Yonghosansugi & Song Myeongheum & Unknown $^{\mathrm{z}}$ & Okcheon-gun & Chungbuk \\
\hline
\end{tabular}

${ }^{\mathrm{z}}$ It is not certain that the age of writing was recorded as unknown, but it is presumed to be the work of the 18th century based on the longevity of the writer.

${ }^{\mathrm{y}}$ The work of 1803 is not included in the 18 th century but is included in the analysis because the author lived in the 18 th century and is close to the 18 th century. 
cultural diversity with experiences overseas such as China and Japan, and absorbed new information and knowledge to build a new information system through active writing activities. Culturally, they broke free from the traditional Confucian interests and focused on flowers, painting, traveling, writing, playing go, and music, producing new cultural contents (Chung, 2007).

This study classified Yusangi in this historical transition of the 18th century according to the five W's and one $\mathrm{H}$, and deduced the contextual meaning. In other words, it classified the behaviors of forest creation into sensory behaviors and general behaviors by examining the writers of Yusangi who went to see nature in the 18th century, such as in which period (age in life history), to what region and mountain (region of Yusan, or sightseeing in the forest and mountain), why they went (motive for Yusan), and what they did in nature including the mountain. As a result, this study analyzed the changes in emotional feelings and rational thoughts, and inferred the meaning.

\section{Results and Discussions}

\section{Age distribution of writers}

Most Yusangi writers are aristocrats, which are the ruling class of the time, as well as intellectuals (Lee, 2014), and determining at what age they enjoyed Yusan will be a meaningful factor to study in relation to forest recreation culture. Among the 21 pieces of Yusangi that were analyzed, 14 of them revealed the age group of the writers, while the other seven did not (Table 2). Most were written by 20 s ( 6 pieces, $28.5 \%$ ), followed by four pieces by $60 \mathrm{~s}(19.0 \%)$, and two each

Table 2. Age distribution of the writer.

\begin{tabular}{lclllcc}
\hline & $20 \mathrm{~s}$ & $30 \mathrm{~s}$ & $40 \mathrm{~s}$ & $50 \mathrm{~s}$ & $60 \mathrm{~s}$ & Unknown \\
\hline Person & 6 & 2 & 0 & 2 & 4 & 7 \\
$(\%)$ & 28.5 & 9.5 & 0 & 9.5 & 19.0 & 33.3 \\
\hline
\end{tabular}

by $30 \mathrm{~s}$ and $50 \mathrm{~s}(9.5 \%)$. Overall, the writers were mostly concentrated in their 20-30s and 50-60s, which is similar to the result of the study by Jung (2003) who analyzed 20 Yusangi related to Geumgangsan. Young people in their 20s enjoyed landscape sightseeing and wrote Yusangi because landscape sightseeing was one of the study methods of the time in addition to spiritual culture, as well as a means to develop great spirit (Jung, 2013). Joseon people who had a relatively shorter life than people today enjoyed landscape sightseeing in their $50-60$ s in the similar way that people today are actively engaged in leisure life after retirement, enjoying composure in their senescence (Park, 2004).

\section{Regional distribution}

18th-century Joseon intellectuals mostly went to Geumgangsan, Jirisan, Gayasan and Cheongryangsan among famous mountains, and enjoyed Yusan activities mostly in places near where they lived or worked as government officials (Lee, 2014). The writers of the Korean translation of Yusangi analyzed in this study also showed a similar aspect (Table 3). Not a single Yusangi was about the Honam region in the 18th century in the Korean translation of Yusangi not because there was no Yusangi but because the excavation of Yusangi was done only recently. There are about 60 Yusangi about the Honam region, 22 of which are about Mudeungsan. Jirisan Yusangi is regionally on Gyeongsang-do and Jeolla-do, but had been classified earlier as Gyeongsang-do Yusangi and were thus excluded from Honam Yusangi (Kim, 2014).

\section{Motive for Yusan}

The reason why Joseon intellectuals went to nature including the mountains for Yusan is directly written in Yusangi or can be inferred from the content. The motive for Yusan of 18thcentury Joseon intellectuals found in Yusangi is mostly the desire for sightseeing. In many cases they expressed that they had wanted to visit that mountain, which indicates that sight-

Table 3. Regional distribution.

\begin{tabular}{lccccc}
\hline & Kangwon & Kyeonggi & Kyoeongsang & Cheola & Chungcheong \\
\hline Volume & 2 & 7 & 7 & 0 & 5 \\
$(\%)$ & 9.5 & 33.3 & 33.3 & 0 & 23.8 \\
\hline
\end{tabular}


seeing was the universal form of traveling for intellectuals in the traditional society of Joseon (Lee, 2014). However, the Korean translation of Yusangi in the 18th century mentioned the specific purpose of sightseeing in some cases, which included Seongho Lee Ik's Youbukangi to look around the newly built Bukhansanseong Fortress (Korea National Arboretum, 2014a), Kang Jaehang's Taebaeksangi to look around the library (warehouse of the Annals of the Joseon Dynasty) (Korea National Arboretum, 2015), and Gosungyougi exploring old castles to find traces of Silla and Goryeo (Korea National Arboretum, 2014b). Their Yusangi of sightseeing in interest in history and relics have clear purpose in terms of their motives and contents. Moreover, there were cases in which evacuating from the plague became the motive of Yusan. Shin Hoin's Deungodosangi (Korea National Arboretum, 2014b) records that he went on mountain climbing when he went to the countryside seeking refuge from the plague. Some cases had symptoms of mental depression as the motive of Yusan, such as Cheongryangsan Yusangi by Park Jong who was one of the people who wrote the biggest number of Yusangi in the 18th century (Lee, 2014).

The motive for Yusan in Yusegeomjeonggi (Korea National Arboretum, 2014a) by Jeong Yak-yong, a typical intellectual in the 18 th century, is more sudden and unpredicted. One summer day he was drinking with his friends around Myeongryebang (currently Myeongdong) near his home in Seoul, when it seemed as if there would be a sudden downpour. He urged his friends to impulsively set out to Yusan together to see Segeomjeong at Bukhansan after rainfall, which shows the passion and enthusiasm of a young intellectual in the 18th century.

\section{Analysis of behavior}

The main interest of Joseon intellectuals in sightseeing was to see the landscape and explore cultural heritages, and they also enjoyed recreational activities such as composing poetry, reading books, discussing, writing epigraphs, swimming and holding rituals for mountain spirits (Jung, 2013). Among these general Yusan activities, the behaviors of the writers in Yusangi are classified into visual behavior, non-visual sensory behavior (auditory and olfactory), and general behavior as shown in Table 4. First, the scope of visual behaviors was extremely wide. The writers looked around the landscape and relics, paid attention to fish in the streams, enjoyed artwork including calligraphic works in temples and memorial halls, and observed the movements of the stars at night (Jeon and Her, 2016). Second, there were rare yet certain behaviors of focusing on sound and fragrance and tasting all kinds of food in the non-visual sensory behaviors. It was interesting how they tasted the region's local food like Manchurian trout and fried and ate beans according to the custom of Yudujeol celebrating the 15th of June (Jeon and Her, 2016). Another behavior worth noticing is that they had others play instruments and listened to it in terms of auditory behavior. Third, general behaviors also show similar aspects with picnics today, showing common activities like writing, reciting and memorizing poetry. The innocent act of Park Je-ga, an intellectual and a classical scholar in the ruling class, skipping stones by the waters reveals the true forest recreation culture (Shim, 2007).

5. Analysis of emotions and thoughts in Yusan and the characteristics of expression

The subjective expressions of writers in Yusangi are analyzed by dividing them into emotional and rational expressions (Table 5). The analysis results showed that in the 18th century, Joseon intellectuals express their emotions and thoughts openly and uniquely while also maintaining enough self-control and moderation. In other words, they express what they like or feel is beautiful in an emotional language, but at the same time shows the character of an intellectual trying to rationally express the essence of an object. It is not easy to clearly classify the writer's subjective expressions into emotional feelings and rational thoughts, but examining the feelings and thoughts of our ancestors in landscape sightseeing by analyzing Yusangi will be an important element in understanding their forest recreation culture.

Many 18th-century Yusangi writers portrayed nature and objects with analogy rather than expressing their feelings, trying to reveal their essence. However, Yusangi writers with the disposition of Silhak show interest in history and national defense, and their Yusangi show frank and simple expressions of emotions in many parts (Chung, 2007). Furthermore, 18thcentury Yusangi writers also showed a lyrical and poetic dis- 
Table 4. Sensory behavior analysis.

\begin{tabular}{|c|c|c|c|c|}
\hline No. & Title & Visual behavior & Non-visual sensory behavior & General behavior \\
\hline 1 & Yousongnisangi & $\begin{array}{l}\text { Chinese emperor's handwriting } \\
\text { appreciation. Enjoy the scenery of } \\
\text { Sunyou-Dong. Watched a temple } \\
\text { (Beopjusa). Watched the autumn } \\
\text { mountain. Read the king's writings. }\end{array}$ & - & $\begin{array}{l}\text { Visit to Hoayangseowon, Trekking } \\
\text { Mt. Nakyoung. } \\
\text { Talk with a monk. }\end{array}$ \\
\hline 2 & Yousamgaksangi & $\begin{array}{l}\text { Enjoyed the scenery of landscape, } \\
\text { waterfall, mountain temple, culture } \\
\text { ruins, west sea, king's castle etc. }\end{array}$ & - & Hiking at dawn. Writing poetry. \\
\hline 3 & Taebaeksangi & - & - & - \\
\hline 4 & Youbukangi & Enjoyed the scenery. & - & Walked around the mountain's castle. \\
\hline 5 & Youcheonmasangi & Enjoyed the scenery and waterfall. & - & $\begin{array}{l}\text { Walked around the temple. Worship } \\
\text { to ancestor at shrine, Hiking. }\end{array}$ \\
\hline 6 & Youkwanaksangi & $\begin{array}{l}\text { Enjoyed the scenery of waterfall. } \\
\text { sunset and cultural inheritance. }\end{array}$ & - & Hiking at dawn. Trekking. \\
\hline 7 & Sobaekyourok & $\begin{array}{l}\text { Looked the scenery of fish in } \\
\text { stream and the azalea. }\end{array}$ & $\begin{array}{l}\text { Listened to a description of the } \\
\text { remains. } \\
\text { Smelled grass. }\end{array}$ & $\begin{array}{l}\text { Recite poetry, Engraved his name in } \\
\text { stone. Sing a song, Writing poetry. } \\
\text { Washed his feet in the stream. }\end{array}$ \\
\hline 8 & Gosungyougi & $\begin{array}{l}\text { Looked the scenery of Pond, } \\
\text { ancient castle, tomb. }\end{array}$ & Appreciated the Kaya harp playing. & - \\
\hline 9 & Yougayasanrok & $\begin{array}{l}\text { Watched a temple. } \\
\text { Appreciated a portrait. Enjoyed the } \\
\text { scenery of Gaya Mt. }\end{array}$ & - & $\begin{array}{l}\text { Planted a pine tree. Attend a Buddhist } \\
\text { education ceremony. }\end{array}$ \\
\hline 10 & Deungyeonjukbonggi & Watched a lush pine tree. & - & - \\
\hline 11 & Youkwanaksangi & Enjoyed the scenery. & $\begin{array}{l}\text { Taken on the aroma of a royal } \\
\text { azalea blossom. }\end{array}$ & $\begin{array}{l}\text { Taken a rest in sperm. Recite poetry. } \\
\text { Hiking at dawn. }\end{array}$ \\
\hline 12 & Youseorakrok & $\begin{array}{l}\text { Enjoyed the scenery of waterfall, } \\
\text { yellow leaves. }\end{array}$ & $\begin{array}{l}\text { Appreciated playing the instrument. } \\
\text { I eat rice in the stream. Drinking } \\
\text { medicine water. }\end{array}$ & - \\
\hline 13 & Yousongniaangi & - & - & $\begin{array}{l}\text { Take off coat and climb a mountain. } \\
\text { Rejected to engrave his name in stone. }\end{array}$ \\
\hline 14 & Yousuraksogi & - & $\begin{array}{l}\text { Drinking. Appreciated the sound of } \\
\text { stream. Eat a snack in a temple. } \\
\text { Smelled grass of valley and } \\
\text { waterfall in the moonlight. }\end{array}$ & $\begin{array}{l}\text { Recite poetry. Trekking. Worship to } \\
\text { ancestor at shrine. Reading. } \\
\text { Discussion, Taking a walk in the } \\
\text { moonlight. Played with exciting. }\end{array}$ \\
\hline 15 & Samdongsansugi & Enjoyed the scenery. & Drinking. & Writing poetry. \\
\hline 16 & Deungodosangi & Enjoyed the flower. & Drinking. & $\begin{array}{l}\text { Recite poetry. Talking, Trekking. } \\
\text { Take a walk in the top. Enjoyed after } \\
\text { party. }\end{array}$ \\
\hline 17 & Yougeumsangi & Enjoyed the scenery of sea \& sunrise. & - & Worship to ancestor at shrine. \\
\hline 18 & Woodusangi & Enjoyed the scenery. & - & Trekking. \\
\hline 19 & Gaeryongsangi & $\begin{array}{l}\text { Enjoyed the scenery of Baekma } \\
\text { river in the top. }\end{array}$ & - & Studied the historical remains. \\
\hline 20 & Youwolsangi & Watched a temple. & $\begin{array}{l}\text { Smelled grass \& take a rest. } \\
\text { Drinking. }\end{array}$ & $\begin{array}{l}\text { Took a walk along the stream. Sing } \\
\text { with pleasure and laugh happily, } \\
\text { Talking. }\end{array}$ \\
\hline 21 & Yonghosansugi & Enjoyed the scenery. & - & - \\
\hline
\end{tabular}

Blank is the case that there is no special act.

Bold text is the main action keyword. 
Table 5. Classification of Blank is the case where no emotional or rational expression is found.

\begin{tabular}{|c|c|c|c|}
\hline No. & Title & Emotional expression & Rational expression \\
\hline 1 & Yousongnisangi & $\begin{array}{l}\text { It is magnificent and brilliant. Admire and shed tears. Be } \\
\text { surprised and obsessed. }\end{array}$ & $\begin{array}{l}\text { Looked at the color of the tree leaves and measured the height } \\
\text { of the mountain. } \\
\text { Playing in the mountains is like studying and waking up the } \\
\text { mind. } \\
\text { How do you know the wisdom of life if you can not enjoy nature } \\
\text { while seeking true pleasure? }\end{array}$ \\
\hline 2 & Yousamgaksangi & - & - \\
\hline 3 & Taebaeksangi & - & - \\
\hline 4 & Youbukangi & - & - \\
\hline 5 & Youcheonmasangi & $\begin{array}{l}\text { Looking at the Silver Waterfall, my eyes and my heart are } \\
\text { getting cool. }\end{array}$ & - \\
\hline 6 & Youkwanaksangi & - & - \\
\hline
\end{tabular}

I washed my body from the stream and seemed to be out of the world.

$7 \quad$ Sobaekyourok

Sitting on a rock near the stream, sings songs, it echoes in the valleys, the wind blows, the water spurts, and there is a fascinating feeling of floating on the raft and the Milky Way.

Looking at the working farmer, I think of the troubles of the mountain peoples. Climbing is a process of studying and reflection.

I realize that the redemption of the temporal lost my true nature and disturbed my mind.

$\begin{array}{lll}8 & \text { Gosungyougi } & \begin{array}{l}\text { I am sad because people do not have an interest in history and } \\ \text { can not know the traces of Silla and Koryo. }\end{array} \\ 9 \quad \text { Yougayasanrok } & \begin{array}{l}\text { The building is magnificent, beautiful, and the statue of the } \\ \text { Buddha is large and outstanding. }\end{array}\end{array}$

The rocks are odd and stark, the water is clear and cool, the valleys are deep and the forests are dense.

10 Deungyeonjukbonggi

11 Youkwanaksangi Before going to the mountains, there is already a cool fragrance.

$12 \quad$ Youseorakrok

$13 \quad$ Yousongnisangi

$14 \quad$ Yousuraksogi

$15 \quad$ Samdongsansugi

form of the world.

16 Deungodosangi

As the mountain grows higher, my breasts become stifling and my breath is blocked. The landscape of the peaks is bright, spacious and of old origin. Stress accumulated in the chest disappears. It is sad that people do not know Confucianism.

17 Yougeumsangi My heart and eyes are refreshing.

The forest is so beautiful that it looks full, it is brilliantly bright, and the strange changes make people pay attention and surprise their minds. The sound of water was as cheerful as playing the

$18 \quad$ Woodusangi harp.

The summit was caught in the sky, and it was high and high, and it seemed to hit the face, and there was the valley of the back of the back, and the soul seemed to run away.

\section{Thinking of the king.}

For a mountain, you need to know its massive body, and for water, you have to see its way through it. Applying the eyes of nature to politics can stabilize all things and embrace people.

-

Through discussion, we realize the truth of the world.

I want to get out of my world. Confucian scholarship is like climbing.

I think that it is a strange scenery in the picture when the boat is crowded and big and small islands are gradually floating on the see.

\begin{tabular}{|c|c|c|c|}
\hline 19 & Gaeryongsangi & - & - \\
\hline 20 & Youwolsangi & - & The flavor of blue is the fruit of the forest. \\
\hline 21 & Yonghosansugi & White sand and stones are as clear as snow and moon. & The scenery is so beautiful that I do not mind recording it. \\
\hline
\end{tabular}

Blank is the case where no emotional or rational expression is found.

Bold text is the main emotional or rational expression keyword. 
position in expressing their subjective emotions, refraining their feelings while expressing them at the same time. Such poetic and lyrical expressions of Yusangi writers are not direct expressions of emotions but can convey enough subjective emotions to the readers. Some examples of such specific expressions are as follows. "In seven or eight days upon coming into the mountain, I ate up all the scenery as if I am beyond heaven and earth with all their spirit, my sleeves filled with the light of the mountains and my clothes filled with the sunset glow, making me no longer look like myself in real world" (Korea National Arboretum, 2015). "Odd rocks and stones face one another east and west or look precipitous behind the rocks, with the mouth open in a cliff and the hollow area like a hole, looking as if a person standing or a tiger crawling......" (Korea National Arboretum, 2013). "The waterway meets the rocks below the pavilion, with the flying waters forming bubbles and the collected waters bringing blue light. The waters flow again (omitted) to a far distance like a spreadout roll of fabric. Royal azaleas just bloomed on the hills, with the wind (omitted) creating a cool air before entering the mountains and causing a distant fragrance" (Korea National Arboretum, 2014a).

\section{Forest recreation culture of 18th-century Joseon}

The 18th century was an era of changes in which there were all kinds of culture and information from abroad and new cultural contents were created. 18th-century Joseon intellectuals overcame the discourse of traditional neo-Confucianism while creating the cultural code of Bukhak from the Qing Dynasty and promotion of public welfare. Books like encyclopedias that summarized all the newly introduced information were published, and there was a trend of new consumer culture with the inflow of foreign culture (Chung, 2007).

However, 18th-century Yusangi still showed many behaviors of following new-Confucian traditions. Lee Hyeonik who wrote Yusokrisangi expresses how he was moved to tears upon facing the writings of a Ming Dynasty emperor in China at Hwayang Seowon. Moreover, intellectuals still treated Buddhist temples as merely an attraction and disregarded Buddhist monks as servants carrying a palanquin, but were observing good manners of worship at seowon. This suggests that the 18th century was the time when foreign culture was introduced and new trends were created, but the traditions of neo-Confucianism still remained deeply rooted in the consciousness of intellectuals.

As a result of analyzing this Korean translation of 18thcentury Yusangi with this background based on five W's and one $\mathrm{H}$, the 18th-century Joseon forest recreation culture can be summarized as follows. Most writers of Yusangi who went sightseeing in the 18th century were government officials or Sadaebu intellectuals that were aristocrats in the ruling class at the time. They enjoyed sightseeing as a universal form of travel since the previous times. They had various goals of sightseeing, but mostly went sightseeing as a daily act of landscape sightseeing, the target areas including not only famous mountains nationwide but also other natural environments around the places where they lived or worked as government officials.

They went sightseeing at a young age in their 20-30s mainly to cultivate their minds or develop great spirit, or at an old age in their 50-60s to relax and enjoy the landscape. Among the motives of Yusan, historical interest appeared as a purpose during this period, which is consistent with the development trend and aim of Silhak in the 18th century. Yusangi writers and their companions in their travel all enjoyed the landscapes and explored cultural heritages, while also additionally composing poetry, reading books and discussing, writing epigraphs, swimming and holding rituals for mountain spirits. As a result of analyzing the behaviors of the writers as sensory behaviors and general behaviors, it was found that there were diverse visual behaviors that included not only seeing and watching, but also observing fish in the streams or stars in the night sky. Furthermore, they showed auditory and olfactory behaviors in which they paid attention to the sounds of nature and enjoyed music played on instruments. As an outcome of these activities, Yusangi shows a variety of expressions about emotional feelings and rational thoughts. Such elaborate expressions of emotional thoughts while refraining from emotional expressions evoke sympathy from people today. Expressions of emotional feelings and rational thoughts, even though they are different from the modern expressions or have moderate emotional expressions, have impressions of nature on people in the modern society that are similar to people in the pre-modern society.

The 18th-century Joseon society was disconnected from the world as it entered the 19th and 20th century due to the inflow 
of Western culture and historical ups and downs. However, the tradition of forest recreation as a culture of intellectuals at the time can be passed down as a forest recreation culture in the modern concept in the following aspects. First, there is abundance in terms of content of the forest recreation. Joseon intellectuals not only hung around in the mountains but also enjoyed natural landscape and showed interest in historical culture, while also using all objects they encountered in the forests for training and learning. Second, while forest recreation was limited to only intellectuals, it was also accepted as a daily culture. 18thcentury Joseon intellectuals always had a desire for sightseeing at the forests, which is clearly displayed in the motive and dailiness of sightseeing by the Yusangi writers. Third, there is a diversity of sensory and general behaviors found in the Yusan behaviors. In the visual aspect, they mostly watched landscape and cultural heritages, showed interest in natural fragrances and sounds, listened to instrumental music, and also were engaged in general forest behaviors including all kinds of play, which will help enrich modern forest recreation culture.

This study has limitations in that it attempted to determine the traditional forest recreation culture through Yusangi in a limited period of time, which is 18th-century Joseon, from the Korean translation of Yusangi. There must be more interest and research on traditional Yusangi to study all Yusangi in the Joseon period in terms of forest recreation culture, thereby building a foundation for modern forest recreation culture and applying it to forest recreation programs today.

\section{Conclusion}

This study examined the Joseon forest recreation culture as a traditional origin of modern forest recreation culture by analyzing the Korean translation of Yusangi published by the Korea National Arboretum written in 18th-century Joseon, and also determined how intellectuals in the pre-modern society saw, felt and responded to nature by examining traditional fores recreation behaviors. The research method consisted of classifying the texts of 18th-century Yusangi based on the five W's and one $\mathrm{H}$, and inference of their meaning. In other words, this study analyzed the changes in emotional feelings and rational thoughts of Yusangi writers who went into nature in the 18th century, based on which period they went and why, and what they did in nature including the mountains. The results showed that most 18th-century Yusangi writers were intellectuals in the ruling class of the time, and the target areas of Yusan included not only famous mountains nationwide but also natural environments of places where they lived and worked as government officials. They went sightseeing at a young age in their 20-30s mainly to cultivate their minds or develop great spirit, or at an old age in their 50-60s to relax and enjoy the landscape. As a result of analyzing the behaviors of the writers into sensory behaviors and general behaviors, it was found that there were diverse visual behaviors that included not only seeing and watching landscapes but also observing fish in the streams or stars in the night sky. Furthermore, they showed auditory and olfactory behaviors in which they paid attention to the sounds of nature and enjoyed music played on instruments. General activities included diverse natural activities like composing poetry or swimming. As an outcome of these activities, Yusangi shows a variety of expressions about emotional feelings and rational thoughts. Such elaborate expressions of emotional thoughts while refraining from emotional expressions evoke sympathy from people today. Among the Yusan culture of 18th-century Joseon intellectuals, cultivating the mind and developing great spirit, the sensory behaviors of enjoying and watching nature, and the general behaviors of hanging out and playing with nature are all suitable for adopting in the forest recreation culture as a modern concept, and will be great traditional materials for enriching our forest recreation culture.

\section{References}

Cheong, Y.S. 2006. Travel's condition of Chosun period. J. Inst. Hmanities 15:123-143. Retrieved from http://www.riss.kr/link?id= A76462544

Chung, M. 2007. The discovery of 18 th century Korean intellectuals. Seoul, Korea: Humanist.

Jang, H.A. 2003. Buddhist monk and a temple in the Chosun dynasty from Yusan-gi. MS thesis, Dongkuk Univ., Kyeongju, Korea.

Jeon, S.Y. and K.J. Her. 2016. Nature travel (Sansoogihaeng) of Joseon intellectuals (Seonbi). Paju, Korea: Dolbegae.

Jung, C.Y. 2003. Traveling practice of literati in the choson dynasty reflected in travel accounts of Mt. Kumgang. J. Cult. Hist. Geogr. 15(3):17-34. 
Jung, C.Y. 2009. A Study on the literati's travels to Mt. Jiri in the Joseon dynasty. J. Korean Geogr. Soc. 44(3):260-281.

Jung, C.Y. 2013. Activities of literati's travels in the Joseon dynasty. Korea Soc. Hist. Folklife Stud. 42:37-70.

Kang, K.Y. 2003. The Yeongnam intellectuals` recognition of the nature in Cheongyansan Yusangi. Yeongnamhak 4:83-115.

Korea Forest Therapy Forum. 2011. Forest therapy. Seoul, Korea: Jeonnamusoop.

Korea National Arboretum. 2013. Travel essays (Yusangi) translated into Korean 1. Paju, Korea: Korean Studies. Information.

Korea National Arboretum. 2014a. Travel essays (Yusangi) translated into Korean 2. Paju, Korea: Korean Studies. Information.

Korea National Arboretum. 2014b. Travel essays (Yusangi) translated into Korean 3. Paju, Korea: Korean Studies. Information.

Korea National Arboretum. 2015. Travel essays (Yusangi) translated into Korean 4. Paju, Korea: Korean Studies. Information.

Korea National Arboretum. 2016. Travel essays (Yusangi) translated into Korean 5. Paju, Korea: Korean Studies. Information.

Kim, J.Y. 2014. Development and effectiveness verification of the forest healing program for children with internet addiction. MS thesis, Chungbuk National Univ., Cheongju, Korea.

Kim, S.Y. 2014. The status and the significance of Honam mountain travel essays. J. Koreanol. 13:210-236.

Lee, D.K. 2012. Ecological management of forests. Seoul, Korea: Seoul National University Press.

Lee, K.S. 2014. Progressive travel narratives: Sajok's travel and their perception of nature in the 17th -18th century Chosun dynasty, Ph.D. Diss., Seogang University, Seoul, Korea.

Lee, S.K. 2011. A study on travel aspect of Sadaebu in Joseon dynasty. Korean Stud. Q. 34(4):37-62.

Lee, S.K. 2013. A study on the travel culture in the Joseon dynasty. Ph.D. Diss., Kangwon National Univ., Chuncheon, Korea.

Lee, S.S., H.Y. Jung, S.H. Ho, and K.M. Kim. 1997. Travel record literature in Joseon middle age. Seoul, Korea: Jipmoondang.

Park, B.W. 1986. Forests as recreational resources, In: J. Kim (eds.). Innovation in forestry management (p. 96-107). Seoul, Korea: Tamgoodang.

Park, H.B. and K.O. Sung. 1993. A study of Korean travel on mountain and river - Focusing on general characteristics. J. Classical Lit. Res. 8:210-232.

Park, M.S. 2004. A study on good use of leisure among the retired elderly in Korea. J. Korean Home Econ. Assoc. 42(12):107-122.

Park, Y.G. 1996. The Joseon dynasty read as a book. Seoul, Korea: Deulyeuk

Park, Y.M. 2005. A study of the 18th century essay about traveling on Cheongryang mountain. Inst. Chin. Characters Korean Lit. Class. Chin. 1:325-357.

Seo, J.B. 2000. Crown dictionary of Korean. Seoul, Korea: Samsung press.

Shim, K.H. 2007. Journey of essay. Seoul, Korea: Igaseo.

Shin, W.S., S.Y. Han, P.S. Yeon, H.K. Kweon, and K.W. Shim. 2011. Forest recreation and therapy. Goyang, Korea: Iroomnamoo. 